\title{
Aqua-toxicological Effects of Water Soluble Fractions (WSF) Of Diesel Fuel On O. Niloticus Fingerlings
}

\author{
*DEDE, E.B. KAGLO, H.D. \\ Department of Pharmacology and Toxicology, College of Health Sciences, University of Port Harcourt, Port Harcourt, Nigeria.
}

\begin{abstract}
Five concentrations of water soluble fraction (WSF) of diesel fuel (1.6 ppm, 3.2ppm, 6.4ppm, $12.3 \mathrm{ppm}$ and $19.2 \mathrm{ppm}$ ) were made. To each of the concentrations of the WSF, ten fingerlings of $O$. niloticus with an average weight of $3 \mathrm{~g}$ were incubated for 96hours. The 96hour $\mathrm{LC}_{50}$ was determined (8.08ppm). Histopathological examination of the fish gills following exposure to the $\mathrm{LC}_{50}$ and $\mathrm{LC}_{100}$ concentrations of the WSF showed gill elongation and lamellar hyperplasia respectively. There was reduction of dissolved oxygen content (from 7.2 to $4.5 \mathrm{mg} / \mathrm{l}$ ) caused by diesel that dissolved in water. This was below acceptable levels for the sustenance of aquatic life (i.e. 6.0 - 8.0 $\mathrm{mg} / \mathrm{L}$ ). However, the $\mathrm{pH}$ reading was not adversely affected. The result tended to suggest that the death of the fingerlings might be related to the decreased dissolved oxygen content of the water due to the presence of diesel. The structural changes of the gills observed may be an adaptation by the fingerlings to oxygen stress. @JASEM
\end{abstract}

A recent study on the contaminating effect of petroleum hydrocarbons on fish species showed that minnows and mullets were found to accumulated aromatic hydrocarbons to as much as $3-4 \mu \mathrm{g} / \mathrm{gm}$ wet weight of the fish. The mullet absorbed the hydrocarbons slowly and depurated them more readily, but the minnows absorbed them rapidly and retained the compounds for as much as two weeks after being transferred to uncontaminated sea water (Khan et al 1995). The current study highlights the possibility that some fishes 9such as minnows) can store aromatic petroleum hydrocarbons from contaminated waters and pass them on to higher trophic levels.

Furthermore, two years after the release of 600,000 litres of diesel fuel into Arthur Harbour in the Antarctic peninsula, spill related contamination was still detected in the intertidal limpet Nacella concinna (Kennicutt and Sweet, 1992), and the fish, Fundulus heteroclitus collected from the Wild Harbour marsh, where a major diesel fuel spill occurred in 1969, was found to contain up to 75ppm of petroleum hydrocarbon in its tissues several year later (Sabo \& Stegeman, 1977)

Contamination of water bodies by hydrocarbons has been shown to produce subtle changes in fish that are both chronically or briefly exposed (Sabo \& Stegeman, 1977) The toxic effects on fish depends on the amount of oil spilled, the area covered by the oil and the chemical characteristics of the oil (Kiihnhold, 1980); the fish species and the duration of influence of the oil one the fish are also important (Onuoha \& Nwachukwe, 1990).

The current study is aimed at investigating the acute toxicological effect of the water soluble fraction of diesel fuel on tilapia (Oreochromis niloticus) fingerlings. It seeks to provide some needed toxicological data on the diesel fuel that is in commercial use in Nigeria, especially on a common tropical fish, O.niloticus; This will include examination of the effect of changes in

\footnotetext{
*Corresponding author
}

physicochemical parameters of the water, ie. $\mathrm{pH}$ and dissolved oxygen content, habitant on the viability of the fish.

\section{MATERIALS AND METHODS}

Eighty fingerlings of tilapia (Oreochromis niloticus) were obtained from the African Regional Aquaculture Centre (ARAC), Aluu - Port Harcourt Nigeria the fingerlings had an average weight of $3 g$. They were conditioned to depended on natural foods for about 14 days, this was intended to simulate conditions obtainable in the natural habitat.

PREPARATION OF WATER SOLUBLE FRACTION (WSF)

One part (IL) of fresh diesel fuel obtained from a filling station, was diluted with four parts (4L) of the water with which the fingerlings were cultured (the control water), in a 6L flask in accordance with Baden (1982). The diesel - water mixture was stirred slowly for 24 hours with a Gallenkamp magnetic stirrer. This was to enhance the dissolution in the water of the water-soluble components of the fuel. The mixture was then made to stand for 3 hours before it was poured into separating funnels and allowed to stand overnight, so as to obtain a clear oilwater interphase. The lower layer of water, containing the WSF of diesel was decanted into containers (Afolabi et al, 1985). This process was repeated several times until sufficient quantity of the WSF was obtained to carry out the study.

EXPOSURE OF TEST ORGANISMS

The WSF was made into five concentrations; 1.6 ppm, 3.2ppm, 6.4ppm, 12.8ppm and 19.2ppm. The dilutions were made with the control water (habitat0 with which the fingerlings were cultured at ARAC; Aluu, near Port Harcourt, Rivers State. Ten fingerlings per group were exposed to 5 litre each of the five concentrations levels of the water soluble fraction (WSF) plus the habitat water as control. The fingerlings were observed for 96 hours. Fingerlings were confirmed dead when they 
no longer responded to prodding (floating in water) Once death was noticed in each of the five concentrations of the WSF, the dead fish was removed. The gill of a dead fingerling from the lowest concentration that killed all the fishes (LG100) was taken out. A representative of the control group was killed and its gill taken out. These gills were preserved in formalin.

$L_{50}$ DETERMINATION

The number of dead fishes per group were recorded against the time of their death in a tabular form as specified by Sprague (1972). The data obtained was used to calculate the median lethal concentration $\left(\mathrm{LC}_{50}\right)$ of the WST of the fuel on O.niloticus fingerlings using Arithmeke method of Karber and Dede (1997). A concentration of the determined $\mathrm{LC}_{50}$ value Igbigke was made by diluting the stock concentration of the WSF, and ten fingerlings were exposed to it; the gill of a dead fingerling from this group was taken out and preserved in formalin.

HISTOPATHOLOGY OF GILL

The preserved gill from the control, $\mathrm{LC}_{50}$ and $\mathrm{LC}_{100}$ groups were processed, embedded in paraffin wax and sectioned with a Shandon AS 325 rotary microtome, and slides were prepared from the sections. Photomicrographs of the sections were made with a Leitz Camera microscope (Diahu 20 model)

PHYSICOCHEMICAL PARAMETERS

The $\mathrm{pH}$ and dissolved oxygen content of the various WSF concentrations and the control water were the physicochemical parameters measured in this study.
The $\mathrm{pH}$ was measured with a La Motte Analogy $\mathrm{pH}$ meter while the dissolved oxygen content of the water was measured with a YS1® Dissolved Oxygen meter.

\section{RESULTS}

(a) Toxity testing of Water Soluble fraction (WSF) diesel fuel oil Oreochromis niloticus fingerlings within 24 hours. Within 24 hours, death was observed with $19.2 \mathrm{ppm}$ WSF diesel fuel (see table 1).

(b) Toxicity testing of water soluble fraction (WSF) diesel fuel in Oreochroms niloticus fingerlings within 48 hours. Within 48 hours death of fingerlings were observed from $12.8 \mathrm{ppm}$ (one death) and with 19.2ppm (two deaths) (see table 2).

(c) Toxicity testing of water soluble fraction (WSF) diesel fuel or Oreochromis niloticus fingerlings within 72 hours. Within 72 hours, deaths of oreochrous niloticus observed with 3.2ppm WSF diesel, 3.2ppm (one death) $6.4 \mathrm{ppm}$ (3 deaths); $12.8 \mathrm{ppm}$ (5deaths) and 19.2ppm (7 deaths) (table 3).

(d) Toxicity lasting of Water soluble fraction (WSF) diesel fuel or Oreochromis niloticus fingerlings within 96 hours fingerlings were observed with $1.6 \mathrm{ppm}$ (2 deaths). $3.2 \mathrm{ppm}$ (3 death). 6.6ppm (5) deaths). 128 ppm ( 7 deaths) and 19.2ppm (10 deaths - all died). See table 4.

TABLE 1: Toxicity Testing at 24 hours

\begin{tabular}{|c|c|c|c|}
\hline CONC (ppm) & No. Surviving & \% alive & \% dead \\
\hline 0 & 10 & 100 & 0 \\
\hline 1.6 & 10 & 100 & 0 \\
\hline 3.2 & 10 & 100 & 0 \\
\hline 6.4 & 10 & 100 & 0 \\
\hline 12.8 & 10 & 100 & 0 \\
\hline 19.2 & 8 & 90 & 10 \\
\hline
\end{tabular}

TABLE 2: Toxicity of Testing at 48 hours

\begin{tabular}{|c|c|c|c|}
\hline CONC (ppm) & No. Surviving & \% alive & $\%$ dead \\
\hline 0 & 10 & 100 & 0 \\
\hline 1.6 & 10 & 100 & 0 \\
\hline 3.2 & 10 & 100 & 0 \\
\hline 6.4 & 10 & 100 & 0 \\
\hline 12.8 & 9 & 90 & 10 \\
\hline 19.2 & 8 & 80 & 20 \\
\hline
\end{tabular}

TABLE 3:Toxicity Test at 72 hours

\begin{tabular}{|c|c|c|c|}
\hline CONC (ppm) & No. Surviving & \% alive & $\%$ dead \\
\hline 0 & 10 & 100 & 0 \\
\hline 1.6 & 10 & 100 & 0 \\
\hline 3.2 & 10 & 90 & 10 \\
\hline 6.4 & 10 & 70 & 30 \\
\hline 12.8 & 10 & 50 & 50 \\
\hline 19.2 & 10 & 30 & 70 \\
\hline
\end{tabular}


TABLE 4: Toxicity Testing at 96 hours

\begin{tabular}{|c|c|c|c|}
\hline CONC $(\mathrm{ppm})$ & No. Surviving & \% alive & \% dead \\
\hline 0 & 10 & 100 & 0 \\
\hline 1.6 & 8 & 80 & 20 \\
\hline 3.2 & 7 & 70 & 30 \\
\hline 6.4 & 5 & 50 & 50 \\
\hline 12.8 & 3 & 30 & 70 \\
\hline 19.2 & 0 & 0 & 100 \\
\hline
\end{tabular}

96 HOURS LC $_{50}$ DETERMINATION: Using Arithmetic method of Karber the $\mathrm{LC}_{50}$ value was determined as follows:

\begin{tabular}{|c|c|c|c|c|c|}
\hline conc (ppm) & $\begin{array}{c}\text { conc. } \\
\text { difference }\end{array}$ & $\begin{array}{c}\text { no. } \\
\text { alive }\end{array}$ & $\begin{array}{c}\text { no. } \\
\text { dead }\end{array}$ & $\begin{array}{c}\text { mean } \\
\text { death }\end{array}$ & $\begin{array}{c}\text { mean death } \\
\text { dose diff }\end{array}$ \\
\hline O (control) & - & 10 & 0 & - & 0 \\
\hline 1.6 & 1.6 & 8 & 2 & 1 & 1.6 \\
\hline 3.2 & 1.6 & 7 & 3 & 2.5 & 4 \\
\hline 6.4 & 3.2 & 5 & 5 & 4 & 12.8 \\
\hline 12.8 & 6.4 & 3 & 7 & 6 & 38.4 \\
\hline 19.2 & 6.4 & 0 & 10 & 8.5 & 54.4 \\
\hline & & & & & 111.2 \\
\hline
\end{tabular}

Table 2: Table for 96 hour LC $_{50}$ determination based on Arithmetic method of Karber. (adapted by Dede 1992).

$$
\begin{aligned}
\mathrm{LC}_{50}= & \mathrm{LC}_{100}-\sum \frac{\text { Mean death } x \text { Conc. Diff. }}{\text { No. of organisms per group }} \\
= & 19.2-\frac{111.2}{10} \\
= & 19.2-11.12 \\
& \mathrm{LC}_{50}=8.08 \mathrm{ppm}
\end{aligned}
$$

TABLE 5: Histopathological findings in the gills of O.niloticus following exposure to the WSF of diesel fuel

\begin{tabular}{|c|c|c|}
\hline Tissue & Concentration & Effect \\
\hline \multirow{3}{*}{ gill } & Control & Normal gill lamellae \\
\cline { 2 - 3 } & $\mathrm{LC}_{50}$ & Elongation of gill lamellae \\
\cline { 2 - 3 } & $\mathrm{LC}_{100}$ & Lamellar fusion and hyperplasia \\
\hline
\end{tabular}

PHYSICOCHEMICAL PARAMETERS:The average values obtained for the physicochemical parameters ( $\mathrm{pH}$ and Dissolved oxygen content) measured for the WSF and control water as compared with the Federal Environmental Protection Agency, (FEPA) standard of water quality for aquatic life (Horsfall \& Spiff, 1998)

TABLE 6: Comparison of the WSF diesel with habitat water based on $\mathrm{pH}$ and dissolved oxygen content.

\begin{tabular}{|c|c|c|}
\hline & $\mathrm{pH}$ & Dissolved oxygen $(\mathrm{mg} / \mathrm{L})$ \\
\hline Water & 7.3 & 4.5 \\
\hline Habitat & 7.8 & 7.2 \\
\hline FEPA & $6.0-9.0$ & $6.0-8.0$ \\
\hline
\end{tabular}

\section{DISCUSSION}

The exposure of O.niloticus fingerlings to watersoluble fraction of diesel fuel showed mortality even at low concentrations. From the international classification of toxicity of substances based on their median lethal concentration $\left(\mathrm{LC}_{50}\right)$ the water soluble fraction (WSF) of diesel fuel is slightly toxic to tilapia fingerlings. This corroborated with previous reports on the effect of water-soluble components of hydrocarbon on aquatic life (Tatem et al, 1978; Kiihnhold, 1980). Histopathological study of the gills showed structural abnormalities such as elongation, fusion and hyperplasia of the lamellae. This agreed with the study of Oladimeji and Onwumere (1988) 
that refinery effluents caused gill damage in $O$. niloticus.

The dissolved oxygen content of the WSF was found to decrease below the FEPA acceptable level for water quality for the sustenance of aquatic organism. The dissolved oxygen tension in aquatic organisms in water contaminated with organic pollutants has been shown to be due to the diversion of the dissolved oxygen meant for respiration to the oxidation of organic pollutant. The extant of depletion of oxygen in the water is often a function of the concentration of the organic pollutants in it (Horsfall \& Spiff, 1998).

The oxygen stress encountered by the fish which is responsible for the respiratory distress and death, was due to their inability to withstand the oxygen depletion of the water induced by the organic compounds in the water soluble fraction of the fuel. Similar oxygen stress imparted by the water soluble fraction of crude oil had been studied in the shrimp, Palaemon adspersus (Baden, 1982) and in the catfish Clarias gariepinus (Igloh etal, 2001 Furthermore, the gill elongation and hyperplasia in the WSFCultured fingerlings may be induced by this oxygen stress.

The $\mathrm{pH}$ of the water was within the FEPA acceptable range for the sustenance of aquatic life (Table 6) and may unlikely contribute to the toxicity of the water soluble fraction.

Improvement on survival of some of the fish with duration of incubation could be the result of enzyme induction which enhanced the rate of breakdown of the pollutants. This confirmed the report that detoxifying enzymes could be induced in fish with prolonged exposure to pollutants (Pyne \& Penrose, 1975).

\section{REFERENCES}

Afolabi O.A.; Adeyemi SA; Imevbore AMA (1985). Studies on toxicity of some Nigerian Crude Oils to some aquatic organisms. In: Proc. Of 1985 Int. Sem on the Petroleum Industry and the Nigerian Environ., Held at Kaduna

Baden SP (1982). Oxygen consumption rate of shrimp exposed to crude oil extract. Mar. Poll. Bull. 13(7): 230-2333.

Dede, E.B. and Igbigbi PS (1997) Determination of LD50 of metakelfn in Rats Journal of Science (Metascience 111 no.1 (1-7)
Horsfall M; Spiff A.I. ( (1998): Principles of Environmental Chemistry. Metropolis Ltd; Port Harcourt, P 112 - 119.

Igboh N.M. Dede, E.B., Ayalogy O.E. (2001) Acute Toxicity effects of crude petroleum (Bonny light) Kerosine and gasoline in Albino Rats (unpublished report)

Kennicutt MC; Sweet ST (1992). Hydrocarbgon contamination on the Antarctic Peninsula III. The Bahia Paraiso two years after the Spill. Mar. Poll. Bull. 25 (9-12): 303 -306.

Khan MAQ; Al-Ghais SM; Al-Marri S (1995) Petroleum hydrocarbon from fish from the Arabian Gulf. Arch. Environ Contam. Toxicol. 29(4): 517 - 522.

Kiihnhold WW (1980). Some aspects of the impact of aquatic oil pollution on fishery resources. FAO/UNDP South China Sea Fisheries development and co-ordinating programme, Manilla, Philipines p1-26.

Oladimeji A.A; Onwumere B.G. (1988). Sublethal effects of treated effluents from the NNPC refinery Kaduna to Oreochromis niloticus (Tilapia). The Petroleum Industry and Nigerian Environment P. 256 - 262.

Pyne J.F; Penrose W.R. (1975). Induction of anythydrocarbon (Benzo(a) pyrene) hydroxylase in fish by Petroleum. Bull. Environ. Contam. Toxicol. 12:481-486.

Sabo D.J.; Stegeman J.J. (1977). Some metabolic effects of Petroleum hydrocarbons in marine fish. In: Physiological response of marine biota to pollutants, verberg F.J; Calabrese A. Thurbury F.P; Boernberg W (eds). Academic Press, New York pp 279 - 287.

Sprague J.B. (1972). The ABC's of pollutant bioassay using fish. A paper presented on environment monitory in Los Angeles, California, June 27 - 28 (ASTM).

Tatem J.W; Cox B.A; Anderson J.W. (1978). The Toxicity of oils and petroleum hydrocarbons to examine crustaceans. Estuarine and coastal Mar Sc. 6:365 - 373. 
